\title{
DETERMINATION OF NOISE POLLUTION IN THE HUDAVENDIGAR URBAN PARK OF BURSA, TURKEY
}

\author{
YALILI KILIC, M. ${ }^{*}$-ABUS, M. N. \\ Bursa Uludag University, Faculty of Engineering, Department of Environmental Engineering, \\ 16059 Bursa, Turkey \\ ${ }^{*}$ Corresponding author \\ e-mail: myalili@uludag.edu.tr; phone: +90-224-294-2117; fax: +90-224-294-2635
}

(Received $5^{\text {th }}$ Mar 2019; accepted $25^{\text {th }}$ Nov 2019)

\begin{abstract}
Noise is one of the health and environmental problems of our age, and it is an undesirable phenomenon that annoys people. Increasing and uncontrolled noise creates physical, physiological and psychological problems, chasing people away from urban life and leading them back to nature. Since the urban parks, which are one of the places to relax, are intensely preferred by people, the noise here should be controlled. In this study, to determine the noise level of the Hudavendigar Urban Park located in the district of Nilufer, Bursa, Turkey, where the transportation routes are intense, measurements were performed, and the results were statistically interpreted. Measurements were carried out at 6 locations selected across the park, in summer, and winter, morning, lunch and evening hours, on weekdays and weekends. In this study, the noise sources indoor and outdoor of the park were determined, and the regions which exceed the limit values given in the Regulation on the Assessment and Management of Environmental Noise were confirmed. As a result of the study, the differences in noise measurements were significant in the summer and winter periods of the Hudavendigar Urban Park according to the statistical analysis.
\end{abstract}

Keywords: noise measurements, noise pollution, recreation area, statistical analysis, urban park, Turkey

\section{Introduction}

The effects of noise on the environment and people have increased by technology, industry and transportation. The noise defined as an unpleasant, unwelcome, uncomfortable acoustic phenomenon has become an environmental problem that needs to be controlled (Şerefhanoğlu, 1991; Aydın and Ateş, 1997).

Today, the effects of noise on the environment and human beings can not be estimated. Temporary or permanent hearing loss occurs in people exposed to prolonged and intense noise. Lower levels of noise make it difficult for people to have mutual communication, cause stress, and insomnia, and hamper human peace and prevent them from working efficiently (Balc1, 1994). With a noisy life, the factors that wear people up and down are increasing. There is a society in which noise resistance and tolerance are increasingly reduced.

Despite the diversity of the effects of noise on human, the limit values related to noise levels and disturbances are given in Table 1 (Donoghue, 2004; Aslan and Y1ldiz, 2017).

The effect of noise on human beings is not only addressed by the high levels of noise, but also by its frequency (Rosenberg, 1991). The level of effect varies according to the duration, severity, frequency of the noise, whether it is continuous or intermittent. Also, the health and age of people exposed to noise cause differences in the degree of influence (Aydın and Ateş, 1997).

Although the term environmental noise generally used for sources outside the structures, noise sources commonly found in the interior environment of the buildings 
and various places. In-building noise sources are particular noises that affect fewer people and can often be prevented with good external insulation (Kurra, 2009; Belek, 2017). Because the external noise sources affect a broader human population, the measures should be at the national level to minimize the noise generated by these sources.

Table 1. Noise levels and disturbances (Donoghue, 2004)

\begin{tabular}{c|c|c}
\hline Degree & Noise Level dB(A) & Disturbances \\
\hline 1 & $30-65$ & $\begin{array}{c}\text { Confusion, discomfort, anger, anger, sleep disorder and concentration disorder } \\
\text { Physiological reactions increased blood pressure, acceleration of heartbeat and } \\
2\end{array}$ \\
respiration, decreased pressure in brain fluid, sudden reflexes \\
3 & $90-90$ & Increased physiological reactions, headaches \\
4 & 120 & Permanent damage to the inner ear, disturbance of balance \\
5 & 140 & Serious brain destruction \\
\hline
\end{tabular}

For this purpose, the Regulation on the Assessment and Management of Environmental Noise (RAMEN) No: 27601, dated 04.06.2010 (Anonymous, 2010), has begun to address noise control at the national level. Also, noise action plans, auxiliary guidelines, and informative publications are prepared by different institutions (Anonymous, 2004, 2011, 2012).

Noise measurements are essential in noise control. Generally, these measurements are performed to check if the environmental noise is within the required limit values or to avoid a negative effect on human (Belek, 2017). The studies on noise pollution have been widely used to determine noise levels from highway traffic (Karaday1, 2001; Aktürk et al., 2003a; Çetin, 2010; Ilgar, 2012; Delikanlı et al., 2014; Sharma et al., 2014; Kalıpç1, 2017), rail systems (Aktürk et al., 2003b; Neitzel et al., 2009; Kablan, 2012; Oruç, 2017) and machinery in some industrial plants (Şahin, 2003; Sakarya, 2016), or to address the effects of noise on human health (Singh and Davar, 2004; Özbıçakçı et al., 2012; Tür, 2016).

There are very few studies on noise pollution in urban parks in the literature (Zannin et al., 2006; Szeremeta and Zannin, 2009; Bayramoğlu et al., 2014; Özer, 2014, 2015, 2017). However, urban parks located within the areas where people can relax in nature by moving away from urban life, are significant for the peace of human life. To control and prevent noise occurring in these areas, the number of studies related to noise pollution should increase.

In this study, noise measurements were carried out at 6 points determined in the Hudavendigar Urban Park in the Nilufer district of Bursa province in the summer and winter periods, and the measurement results were evaluated statistically. The noise sources inside and outside the park were determined, and the regions exceeding and approaching the limit values were specified in the RAMEN.

\section{Materials and Method}

Hudavendigar Urban Park created on both sides of the Nilufer Stream of Bursa city in Turkey, is the largest urban park in the city, which has an area of approximately 510 thousand $\mathrm{m}^{2}$. The measurements were carried out to determine the noise level in the park, which is in the center of the city and in an area with high access roads. 
In the study, firstly the methods of noise pollution studies were investigated (Bayramoğlu et al., 2014; Özer, 2014, 2015), and sensitive points in terms of noise were determined by looking at the map of the park. When determining the points, parking entrance and exit points, parking lot, proximity to motor traffic, tennis courts and football fields were taken into consideration. These points are shown on the map (Figure 1) by giving measurement numbers, the coordinates of the measurement points are given in Table 2.

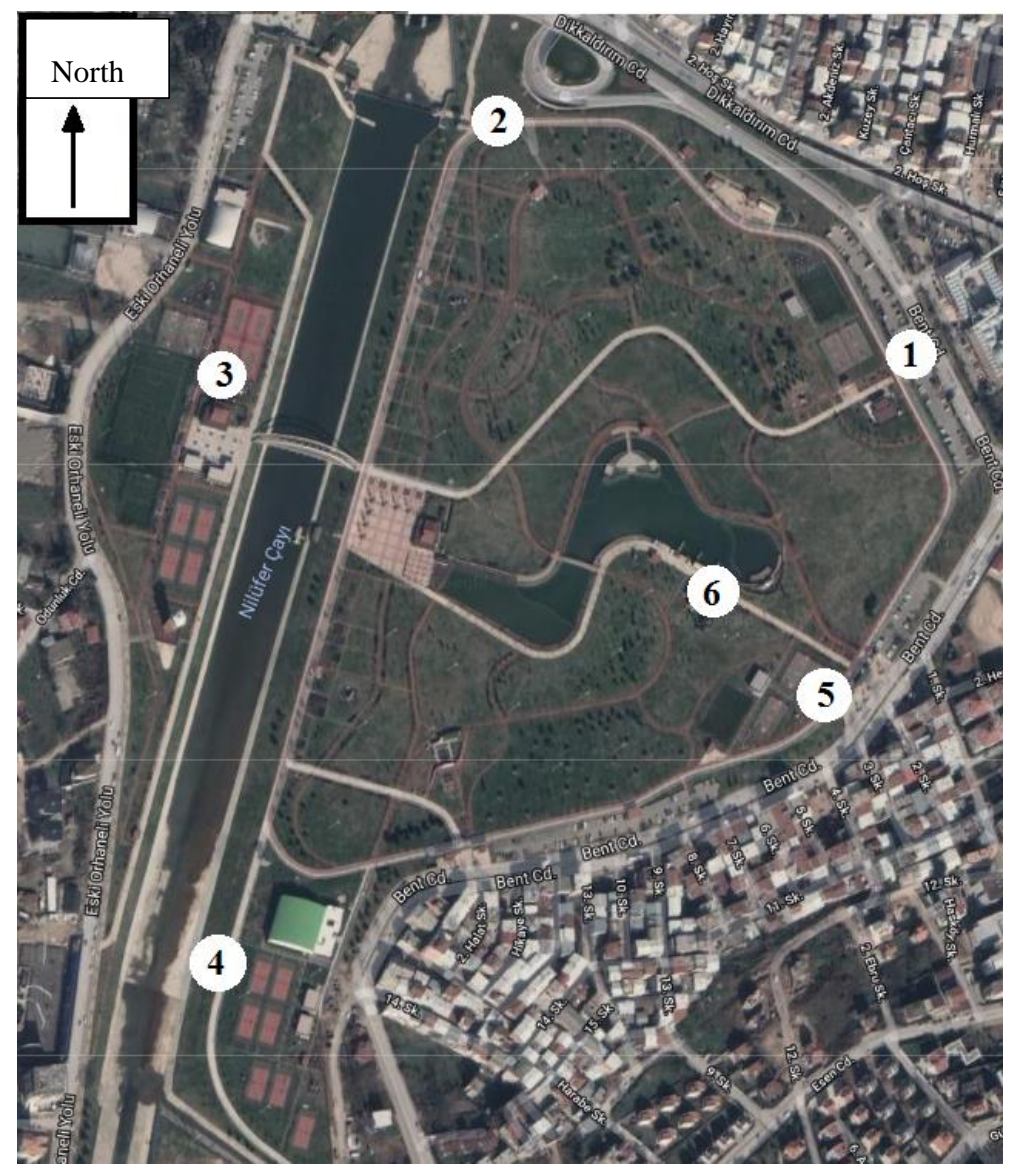

Figure 1. Display of measurement points on the map (Anonymous, 2018a)

Table 2. The coordinates of measurement points (Anonymous, 2018b)

\begin{tabular}{c|cc}
\hline \multirow{2}{*}{ Measurement points } & \multicolumn{2}{|c}{ Measurement coordinates } \\
\cline { 2 - 3 } & $\mathbf{x}$ & $\mathbf{y}$ \\
\hline 1 & 670544.22 & 4452165.38 \\
3 & 670212.43 & 4452358.63 \\
4 & 670012.58 & 4452166.61 \\
5 & 670026.68 & 4451687.42 \\
6 & 670499.32 & 4451918.18 \\
& 670403.56 & 4452005.65 \\
\hline
\end{tabular}

The noise measurements were made at determined points on Monday and Thursday on weekdays and Saturday or Sunday, at the weekend, in the morning, lunch and evening times, in October, November, December in 2016 and July, August, September 
in 2017. The measurements were carried out in three minute periods on sunny days when the weather was rainless and windless. The measurement hours are 08:00-09:00 a.m., 12:00-1:00 p.m. and 5:00-6:00 p.m. according to the overtime start-end hours, and people may prefer to go to the park.

The noise measurements were taken from a height of 1.2 meters to a location at a 45-degree angle, close to the traffic roads that limit the parking areas and from the middle of the parking area (Göksu and Karabulut, 2014). It was taken to measure at least $1.5 \mathrm{~m}$ away from the noise reflective surfaces, such as trees, walls, and buildings in order not to cause the noise to be reflected and cause the actual noise to taken incorrectly. All subsequent measurements were taken from the same points and positions, the first measurement conditions (same point, same height, same direction, same time, etc.) were not changed (Morgül and Dal, 2012). Average air temperature, humidity and wind speed at the time of measurement are recorded.

The sound meter (EXTECH 407738, Massachusetts, USA) was used to determine the noise level in this study. The measurements are in the maximum equivalent noise level (Leqmax) and are in the A-weighted volume (dBA) unit. In this context, the 90 values from the single point of the park, a total of 540 values from 6 points were determined and Leq, which is the equivalent noise level, is translated according to formula 1.

$$
\operatorname{Leq}=10 \log 1 / 10 \sum_{i=1}^{n} 10^{L i / 10}
$$

where,

- Leq : Equivalent noise level (dBA).

- $\mathrm{n}$ : Number of noise measurements.

- Li : Noise level in measurement.

Thus, for a total of 27 hours in the park, 30 days measurements were made. These values were subjected to oneway variance analysis in a general linear model by using JMP 7 (SAS Inst. Inc., NC, USA) software, and their importance status was examined. Means were compared with LSD test by using MStatC software. The reasons for the values were evaluated and discussed according to the RAMEN.

\section{Results and Discussions}

This study was carried out on the determination of noise pollution in the Hudavendigar Urban Park located in Nilufer district of Bursa, Turkey. The noise measurements of the park were carried out in successive winter and summer periods. A comparison of minimum, maximum and average values for the summer and winter periods was performed at 6 points determined in the park and the number of measurements exceeding $65 \mathrm{dBA}$ which is the limit in RAMEN were given in Table 3. The variance analysis results were given in Table 4. The differences between seasons, measurement points and measurement time were significant statistically during the study period $(\mathrm{P}<0.01)$. But the variation within measurement days was not significant $(\mathrm{P}>0.05)$. Noise levels in the park evaluated according to the noise-sensitive areas in the RAMEN Appendix VII, and 245 of the total 540 measurements were found to exceed the limit value of $65 \mathrm{dBA}$ during the day. The regional, seasonal and temporal changes of noise measurements in Hudavendigar Urban Park and the possible sources of noise levels are discussed in detail in the following sections. 
The average noise level of the Hudavendigar Urban Park was determined as 64.63 dBA. The average noise levels in other studies are $66.62 \mathrm{dBA}$ in Yüzüncüyıl Park in Erzurum (Özer, 2017), 67.69 dBA in Aziziye Park (Özer, 2014), 60.07 dBA in Yakutiye Park (Özer, 2015), 63.74 dBA in Meydan Park in Trabzon and $64.67 \mathrm{dBA}$ in Fatih Park (Bayramoğlu et al., 2014). These results show that the average noise levels in urban parks are close to each other.

Table 3. Comparison of descriptive statistics and limit values for summer and winter measurements of determined points

\begin{tabular}{c|cccc|cccc}
\hline \multirow{2}{*}{ Point } & \multicolumn{4}{|c|}{ Winter measurements } & \multicolumn{4}{c}{ Summer measurements } \\
\cline { 2 - 8 } & $\begin{array}{c}\text { Min } \\
(\mathbf{d B A})\end{array}$ & $\begin{array}{c}\text { Max } \\
\text { (dBA) }\end{array}$ & $\begin{array}{c}\text { Average } \\
(\mathbf{d B A})\end{array}$ & $\begin{array}{c}\text { Number of } \\
\text { measurements } \\
\text { exceeding 65 dBA }\end{array}$ & $\begin{array}{c}\text { Min } \\
\text { (dBA) }\end{array}$ & $\begin{array}{c}\text { Max } \\
(\mathbf{d B A})\end{array}$ & $\begin{array}{c}\text { Average } \\
\text { (dBA) }\end{array}$ & $\begin{array}{c}\text { Number of } \\
\text { measurements } \\
\text { exceeding 65 dBA }\end{array}$ \\
\hline 1 & 60.8 & 90.8 & 71.7 & 43 & 65.7 & 86.6 & 74.3 & 45 \\
2 & 58.8 & 84.3 & 67.6 & 30 & 51.9 & 78.6 & 61.0 & 11 \\
3 & 49.9 & 74.5 & 59.0 & 6 & 51.0 & 87.8 & 64.9 & 22 \\
4 & 47.0 & 62.8 & 54.7 & 0 & 52.4 & 74.4 & 61.2 & 14 \\
5 & 49.9 & 83.7 & 68.0 & 31 & 50.0 & 85.0 & 74.0 & 43 \\
6 & 46.7 & 69.4 & 58.2 & 4 & 49.0 & 77.8 & 61.0 & 12 \\
\hline
\end{tabular}

Table 4. Variance analysis table for all parameters

\begin{tabular}{c|c|c|c|c|c}
\hline Source & DF & Sum of Squares & Mean Square & F Ratio & Prob > F \\
\hline Season & 1 & 1008.6 & 1008.6 & 13.0672 & $<0.0003^{*}$ \\
Points & 5 & 17112.015 & 3422.4 & 71.88 & $<0.0001^{*}$ \\
Time & 2 & 1598.561 & 799.28 & 10.485 & $<0.0001^{*}$ \\
Day & 14 & 598.93 & 42.787 & 0.5356 & 0.9124 \\
\hline
\end{tabular}

$* \mathrm{P}<0.05$ level is significant

\section{Regional Variations of Noise Measurements}

The 1st point is the most used area of Hudavendigar Urban Park's entrance-exit gates. At the same time, it looks at Dikkaldırım Street, where there is heavy traffic. The measured values were higher than the park average for winter and summer measurements because the park is an entrance-exit zone, and due to high number of people-related mobility and the proximity to the street. The measured values at this point of the park have generally increased as a result of vehicles. Traffic lights around the measuring points increased the car stop-start, while the noise of the horns increased in parallel with the traffic during the pedestrian crossing and the work hours. The road traffic noise in Bursa had become a significant problem in a study conducted by Karaday1 (2001). This result supports the conclusion that the traffic noise around Hudavendigar Urban Park also increases the noise level in the park. As a result of the 1 st point measurements, the maximum value was $90.8 \mathrm{dBA}$, and 88 out of 90 measurements exceeded $65 \mathrm{dBA}$.

The selected point 2 is on the walking path of Hudavendigar Urban Park, located in the vicinity of the bridge where Nilufer River is lowered from a certain height and is close to the intersection of Dikkaldirım Street, where the traffic of motor vehicles is much. While noise levels increased overall at all points during the summer period, there were decreases in the noise levels at the 2 nd point, and the measurement results which exceeded the RAMEN limit value of $65 \mathrm{dBA}$. Because the water level of the river is low 
in this area and the intersection works during the winter months increased the noise in this period. The maximum noise level of the 2 nd point was $84.3 \mathrm{dBA}$, and 41 of 90 measurements exceeded $65 \mathrm{dBA}$, which is the limit value of RAMEN.

The $3^{\text {rd }}$ point located in the western part of the Hudavendigar Urban Park, where the football fields and the children's playground are densely populated. With the increase in the use of football fields and children's playground at this point in the summer, especially at noon and evening times, the noise levels increased more than $10 \mathrm{dBA}$ on average according to winter. As a result of the measurements at point 3 , the maximum value was $87.8 \mathrm{dBA}$, and 28 out of the 90 measurements exceeded $65 \mathrm{dBA}$, which is the limit value of RAMEN.

Nilufer River flows around the 4th point of the park, and there are picnic areas, benches, tennis courts and one watchtower. Because the tennis games took place in the closed area in winter, there were no sound levels to create unrest. However, in the summer period, the level of noise increased when the tennis was played on open courts. Especially in the winter period, the value above $65 \mathrm{dBA}$ which is the RAMEN limit value is not read, in summer period the value above $65 \mathrm{dBA}$ is recited 14 times. While the maximum noise level was $87.8 \mathrm{dBA}$, it was that 14 out of the 90 measurements in total exceeded $65 \mathrm{dBA}$.

There are children's amusement parks, basketball courts and kiosks around the 5th point, which is overlooking the entrance and exit doors of the park and Bent Street. The measured values are very close to or exceeded the limit value because this point is a park entrance and exit zone, and due to the high number of people-related mobility, closeness to the street and the presence of children's amusement parks, basketball fields and kiosks. The maximum noise level was $85.0 \mathrm{dBA}$, and 74 of the total 90 measurements made at this point were found to exceed $65 \mathrm{dBA}$, which is the limit value of RAMEN.

There is a large tea garden, restaurant and lake around the 6th point selected in the center of the park. Due to the preference of closed areas during winter, the results are generally below the limit values. However, with the warm weather, the preference of the tea garden and the open spaces of the restaurant, the opening of loud music in the tea gardens and the choice of kayak trips on the lake increased, the noise levels increased towards the evening hours. As a result of the measurements at point 6 , the maximum value was $77.8 \mathrm{dBA}$, and 16 out of 90 measurements exceed the limit value of $65 \mathrm{dBA}$ in the RAMEN.

When the results of the noise measurement values at 6 points in the park were examined, the differences between these values was statistically significant (Table 5). According to these results, the highest noise level was at the 1st point during the study. The 1st point of the noise measurements in Hudavendigar Urban Park is the most used area of the entrance-exit gates and at the same time looking at the Dikkaldirım Street where the traffic is heavy, explains why the highest noise values were obtained at this point.

Table 5. Variation of noise levels among measurement points

\begin{tabular}{c|c|c|c|c|c|c|c}
\hline Points & $\begin{array}{c}\text { Min } \\
(\mathbf{d B A})\end{array}$ & $\begin{array}{c}\text { Average** } \\
(\mathbf{d B A})\end{array}$ & $\begin{array}{c}\text { Median } \\
(\mathbf{d B A})\end{array}$ & $\begin{array}{c}\text { Max } \\
(\mathbf{d B A})\end{array}$ & $\begin{array}{c}\text { Standard } \\
\text { deviation }\end{array}$ & $\begin{array}{c}\text { Standard } \\
\text { error }\end{array}$ & $\begin{array}{c}\text { LSD } 0.05 \\
\text { Value }\end{array}$ \\
\hline 1 & 60.80 & $73.00^{\mathrm{a}}$ & 72.30 & 90.80 & 5.24 & 0.55 & \\
2 & 51.90 & $64.26^{\mathrm{b}}$ & 63.75 & 84.30 & 6.94 & 0.73 & 2.94 \\
3 & 49.90 & $61.96^{\mathrm{bc}}$ & 60.30 & 87.80 & 8.81 & 0.93 & \\
\hline
\end{tabular}




\begin{tabular}{l|l|l|l|l|l|l|l}
\hline 4 & 47.00 & $57.97^{\mathrm{d}}$ & 56.65 & 74.40 & 6.04 & 0.63 & \\
5 & 49.90 & $71.05^{\mathrm{a}}$ & 72.75 & 85.00 & 7.25 & 0.76 & \\
6 & 46.70 & $59.41^{\mathrm{cd}}$ & 58.85 & 77.80 & 6.58 & 0.69 & \\
\hline
\end{tabular}

${ }^{* *} \mathrm{P}<0.0001$ level is significant, ${ }^{\mathrm{a}-\mathrm{d}}$ Means in a column with different superscripts significantly differ.

\section{Seasonal Variations of Noise Measurements}

There were differences in noise measurements of Hudavendigar Urban Park, in the summer and winter periods. The noise sources inside and outside the park for summer and winter periods caused the differences. The maximum noise levels for the summer and winter measurements of 6 points determined in Hudavendigar Urban Park are shown in Figure 2.

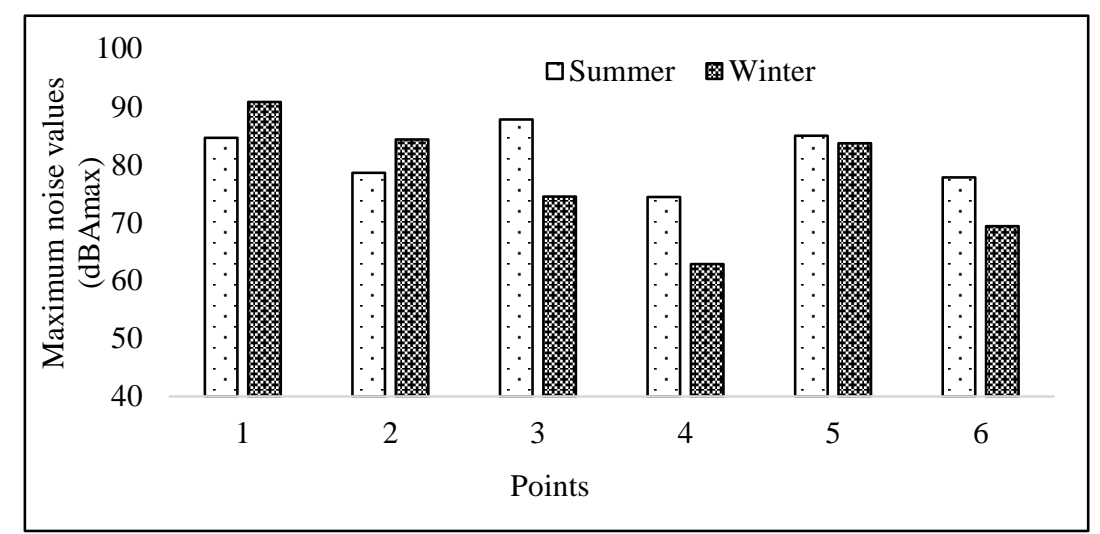

Figure 2. Maximum noise levels according to the points in summer and winter measurements

In the winter measurements of the Hudavendigar Urban Park, traffic-related noise has come to the fore. Since sports and recreation activities are carried out in closed areas, noise caused by these activities has remained passive according to non-park noise sources. 110 out of 270 measurements carried out during the winter period exceeded 65 $\mathrm{dBA}$ which is the limit value of RAMEN.

With the increase in the use of sports and recreation activities in summer, the noise levels caused by these activities increased significantly compared to winter. Trafficinduced noise levels are close to winter measurements. 135 out of 270 measurements carried out during the summer period were over $65 \mathrm{dBA}$, the limit of RAMEN. According to the statistical evaluation of winter and summer measurements, the difference between the measurement values of the two seasons was significant (Table 6).

Table 6. Variation of noise levels among seasons

\begin{tabular}{c|c|c|c|c|c|c|c}
\hline Season & $\begin{array}{c}\text { Min } \\
\text { (dBA) }\end{array}$ & $\begin{array}{c}\text { Average }^{* *} \\
(\mathbf{d B A})\end{array}$ & $\begin{array}{c}\text { Median } \\
\text { (dBA) }\end{array}$ & $\begin{array}{c}\text { Max } \\
\text { (dBA) }\end{array}$ & $\begin{array}{c}\text { Standard } \\
\text { deviation }\end{array}$ & $\begin{array}{c}\text { Standard } \\
\text { error }\end{array}$ & $\begin{array}{c}\text { LSD } 0.05 \\
\text { Value }\end{array}$ \\
\hline Winter & 46.70 & $63.24^{\mathrm{b}}$ & 62.90 & 90.80 & 8.43 & 0.51 & 4.22 \\
Summer & 49.00 & $65.98^{\mathrm{a}}$ & 66.60 & 87.80 & 9.12 & 0.56 & \\
\hline
\end{tabular}

\footnotetext{
${ }^{* *} \mathrm{P}<0.0001$ level is significant, ${ }^{\mathrm{a}-\mathrm{b}}$ Means in a column with different superscripts significantly differ.
} 
In a study on the determination of noise pollution caused by traffic and recreational use in Çorlu city, noise levels were higher in winter than in other periods. It is thought that the population density in the region and accordingly the number of vehicles are not to decrease by winter holidays etc. (Ünver, 2008). In the Hudavendigar Urban Park, while the noise levels were higher in the regions close to the transportation roads during the winter months, it was observed that there were lower levels in park areas in winter when compared to the summer season. In a study conducted in Düzce city, the noise values of the park areas in summer were higher than in winter (Yerli and Demir, 2015). The results show that the parking areas are used more intensively in summer than in winter, and similar results also considered for Hudavendigar Urban Park.

\section{Temporal Changes of Noise Measurements}

In summer and winter measurements, there are more traffic and vehicle-related noise increases in the morning times during the week, and there is an increase in noise levels due to the active use of sports and recreation areas in the lunch and evening times during the weekend.

\section{Noise levels according to morning, noon and evening hours}

The maximum noise levels of 6 points determined in Hudavendigar Urban Park in the morning, noon, and evening times during the winter and summer periods are shown in Figure 3.
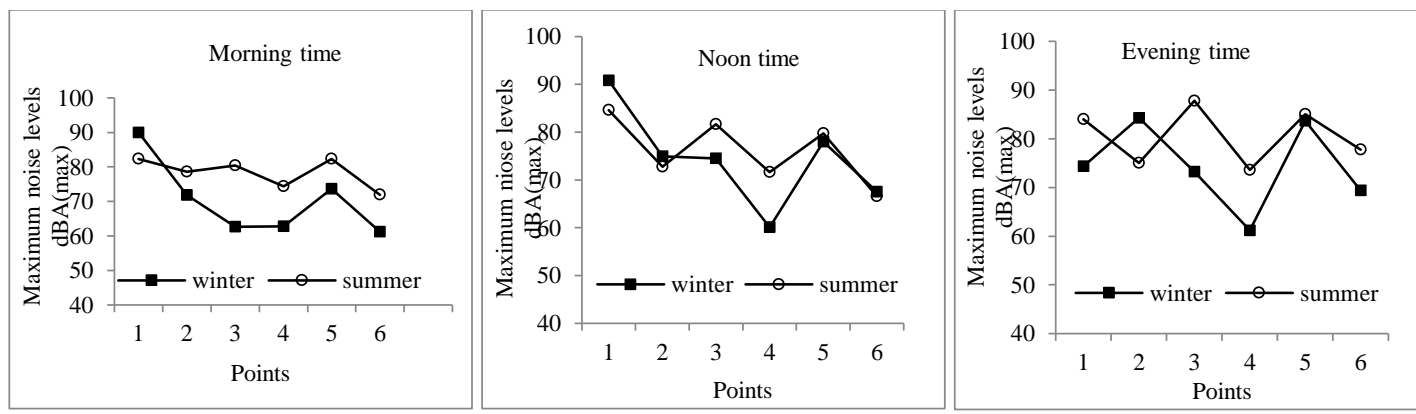

Figure 3. Maximum noise levels of winter and summer periods according to morning, noon and evening hours

In the morning measurements, the maximum value was at the 1st point with $90 \mathrm{dBA}$. Since the morning measurement time interval is the time for people going to work by their vehicles, significant traffic density has been observed mainly on the streets near the 1 st and 5th points and high noise levels have been read at these points.

The maximum value was $90.8 \mathrm{dBA}$ and $84.6 \mathrm{dBA}$ at the 1 st point in the winter and summer periods, respectively. There were substantial differences in noise levels between the 3rd and 4th points at noontime because children's playgrounds at these points and activities such as football and tennis are preferable at noon during the summer.

The maximum value of the park points in the evening hours was $87.8 \mathrm{dBA}$ at the 3rd point in the summer period. In the summer period, noise levels increased due to the active use of sports and recreation areas. The differences between the measurement 
times of noise values were significant according to statistical analysis $(\mathrm{P}<0.0001)$ (Table 7).

The highest noise value was measured as $68.75 \mathrm{dBA}$ in the evening at the Yüzüncü Y1l Park in Erzurum (Özer, 2017), in another study conducted in Aziziye Park (Özer, 2014), the highest noise value in the evening time was read as $69 \mathrm{dBA}$, the highest noise value in Yakutiye Park (Özer, 2015) was determined as 64.29 dBA in the evening. In Hudavendigar Urban Park, the highest noise value was $77.4 \mathrm{dBA}$ in the evening time. In a study conducted in the Düzce city of Turkey, the parking areas were used more intensively and until late hours in the summer than in winter. The noise levels in day and evening in summer are higher than in winter months (Yerli and Demir, 2015). A similar situation exists for Hudavendigar Urban Park.

Table 7. Variation of noise levels among measured times

\begin{tabular}{c|c|c|c|c|c|c|c}
\hline Hours & $\begin{array}{c}\text { Min } \\
(\mathbf{d B A})\end{array}$ & $\begin{array}{c}\text { Average }^{* *} \\
(\mathbf{d B A})\end{array}$ & $\begin{array}{c}\text { Median } \\
(\mathbf{d B A})\end{array}$ & $\begin{array}{c}\text { Max } \\
(\mathbf{d B A})\end{array}$ & $\begin{array}{c}\text { Standard } \\
\text { deviation }\end{array}$ & $\begin{array}{c}\text { Standard } \\
\text { error }\end{array}$ & $\begin{array}{c}\text { LSD } 0.05 \\
\text { Value }\end{array}$ \\
\hline Morning & 46.70 & $62.41^{\mathrm{b}}$ & 60.55 & 90.00 & 9.22 & 0.69 & \\
Noon & 49.00 & $64.81^{\mathrm{a}}$ & 65.00 & 90.80 & 8.94 & 0.67 & 2.00 \\
Evening & 50.20 & $66.61^{\mathrm{a}}$ & 66.90 & 87.80 & 7.99 & 0.59 & \\
\hline
\end{tabular}

${ }^{* *} \mathrm{P}<0.0001$ level is significant, ${ }^{\mathrm{a}-\mathrm{b}}$ Means in a column with different superscripts significantly differ.

\section{Noise levels of weekday and weekend}

The change in the levels of weekday and weekend noise measurements of 6 points in the Hudavendigar Urban Park in the winter and summer periods are shown in Figure 4.

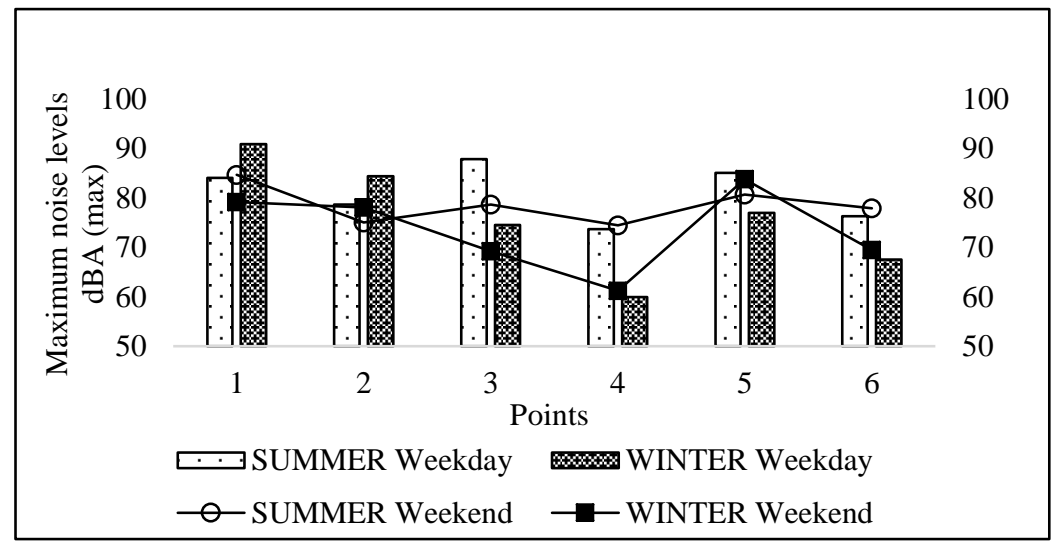

Figure 4. Maximum noise values during weekdays and weekends in winter and summer periods

As seen in Figure 4, there is a general increase in noise levels according to the winter period measurements in the weekday values of the summer period. There are increases in the summer period noise levels due to more summer activities in the park. Due to the intersection work carried out in the north of the park during the weekdays in the winter period, both the equipment used and the traffic generated caused an increase in noise levels at points 1 and 2 . 
There is an increase in summer measurements at weekends. It is thought to be because in-park activities are carried out in open areas and people prefer to use the park in hot weather.

\section{Conclusions}

In this study, measurements were made to determine the noise level in the Hudavendigar Urban Park, located in the Nilufer district of Bursa, which is an important recreation area for the urban population. These measurements were carried out for a total of 30 days during the summer and winter periods, including morning, lunch and evening hours. Observations and statistical data interpreted the measurement results. It was determined that the sensitive points exceed the limit values specified in the RAMEN and approach the limit values, and the points with noise differences have been associated with the purposes of the park. The findings of the measurements are summarized below:

- The traffic noise was prominent in the winter period measurements of the Hudavendigar Urban Park. Since sports and recreation activities are carried out in closed areas, noise caused by these activities is passive according to non-park noise sources. The 110 of 270 measurements exceeded $65 \mathrm{dBA}$, which is the limit value of RAMEN. In winter measurements, the highest value was $90.8 \mathrm{dBA}_{(\max )}$ at the 1 st point in November.

- With the increase in the use of sport and recreation activities in the park in summer, the noise levels caused by these activities have increased significantly compared to winter measurements. Traffic-induced noise levels are close to winter measurements, and 135 out of 270 measurements exceeded $65 \mathrm{dBA}$. In summer measurements, the highest value was $84.6 \mathrm{dBA}_{(\max )}$ at the 1 st point in noontime in July.

- In summer and winter measurements, traffic and vehicle noise increased throughout the park in the morning, and noise levels increased due to active use of sports and recreation areas especially at noon and evening hours during the summer. In the morning and noon measurements, the highest values were read in the summer and winter periods at the 1st point, while the highest winter values in the evening measurements were at the 5th point and the highest summer value at the 1 st point. The highest values of the morning hours are $82.3 \mathrm{dBA}(\max )$ in summer and $90 \mathrm{dBA}$ $(\max )$ in winter, the highest values of noon are $84.6 \mathrm{dBA}(\max )$ in summer and 90.8 $\mathrm{dBA}(\max )$ in winter, the highest values of the evening hours were $85 \mathrm{dBA}(\max )$ in summer and $84.3 \mathrm{dBA}(\max )$ in winter.

- The noise levels during the weekdays in the summer period showed a general increase compared to the winter period. This increase is due to the more use of activities in the park in summer. In winter measurements, the high values in points 1 and 2 are affected by the intersection study in the north of the park and the traffic. The highest noise measurement value on weekdays was read at $90.8 \mathrm{dBA}_{(\max )}$ at noon in November at the 1st point in winter.

- On the other hand, there is an increase in the summer measurements. Because in-park activities are carried out in open areas, and people prefer the park more in hot weather. The highest value of the weekend was read as $84.6 \mathrm{dBA}_{(\max )}$ at noon in July at the 1 st point in summer.

As a result of this study, which was carried out to determine noise pollution in urban parks in Bursa, the differences in noise measurements in summer and winter periods in 
Hudavendigar Urban Park were observed. It was interpreted as a result of the measurements that the vehicle traffic around the park increased the noise level in the winter period, and the intensive use of the activities in the park increased the noise level, especially in the summer. It was concluded that it would be beneficial to take various measures by focusing on the noise-enhancing factors in the park to prevent people coming to the urban park to relax from these levels and not to exceed the RAMEN limit value.

Acknowledgements. The authors would like to thank Assoc. Prof. Ilker Kilic for his statistical evaluation of the manuscript.

\section{REFERENCES}

[1] Aktürk, N., Akdemir, O., Üzkurt, İ. (2003a): Environmental noise caused by traffic lights timing and traffic volume (Trafik 1şı sürelerinin neden olduğu çevresel taşıt gürültüsü). Journal of the Faculty Engineering and Architecture of Gazi University 18(1): 71-87.

[2] Aktürk, N., Toprak, R., Asiloğulları, E. (2003b): Environmental noise caused by rapid rail transit systems (Hızlı raylı ulaşım sistem kaynaklı çevresel gürültü). - Journal of the Faculty Engineering and Architecture of Gazi University 18(3): 15-25.

[3] Anonymous (2004): https://webdosya.csb.gov.tr/db/ced/icerikler/turk-yecevreatlas-20180514084340.pdf. Date of access October 16, 2018.

[4] Anonymous (2010): https://www.mevzuat.gov.tr/Metin.Aspx?MevzuatKod=7.5.14012 \&MevzuatIliski=0\&sourceXmlSearch $=\% \mathrm{C} 3 \%$ A7evresel. Date of access October 16, 2018.

[5] Anonymous (2011): https://webdosya.csb.gov.tr/db/cygm/icerikler/cevresel-gurultuolcum-ve-degerlend-rme-klavuzu-20180209145104.pdf. Date of access October 16, 2018.

[6] Anonymous (2012): http://megep.meb.gov.tr/mte_program_modul/moduller_pdf/ G\%C3\%BCr\%C3\%BClt\%C3\%BCn\%C3\%BCn\%20Etkileri.pdf. Date of access October 16, 2018.

[7] Anonymous (2018a): https://www.google.com/maps/@40.2007089,29.0015165,874m/ data $=! 3 \mathrm{~m} 1 ! 1 \mathrm{e} 3$ ?hl=tr-TR. Date of access April 2, 2018.

[8] Anonymous (2018b): https://www.google.com/earth/versions/\#earth-pro. Date of access December 28, 2018.

[9] Aslan, Ş., Yıldız, S. (2017): Noise assessment of water and wastewater treatment plants (Atıksu ve içme suyu arıtma tesisinde gürültü kirliliği değerlendirmesi). - Cumhuriyet Science Journal 38-4: 798-812.

[10] Aydın, M. E., Ateş, N. (1997): Traffic noise in Konya and some proposals (Konya'da trafik gürültüsü ve bazı öneriler). - Pamukkale University Journal of Engineering Sciences 3(3): 447-456.

[11] Balc1, A. N. (1994): Bir çevre kirlenmesi sorunu olarak gürültü (in Turkish). - İstanbul Üniversitesi Orman Fakültesi Dergisi 44(3-4): 15-34.

[12] Bayramoğlu, E., Özdemir Işık, B., Demirel, Ö. (2014): The effect of noise pollution on city parks and proposed solutions: case of Urban Trabzon (Gürültü kirliliğinin kent parklarına etkisi ve çözüm önerileri: trabzon kenti örneği). - Inonu University Journal of Art and Design 4(9): 35-42.

[13] Belek, C. (2017): A research and a case study on the effect of environmental noise on accommodation facilities (Çevresel gürültünün konaklama tesislerine olan etkisi üzerine bir araştırma ve bir örneklem). - MSc. Thesis, Graduate School of Natural and Applied Sciences, Gazi University, Ankara. 
[14] Çetin, F. (2010): Traffic noise pollution map of Denizli province (Denizli ili trafik gürültü kirliliği haritası). - MSc. Thesis, Health Sciences Institute, Celal Bayar University, Manisa.

[15] Delikanlı, N. E., Yücedağ, C., Kapdı, A. (2014): A preliminary study on noise pollution from vehicle traffic in Bartın City (Bartın kentinde araç trafiğinden kaynaklı gürültü kirliliği üzerine bir ön çalışma). - Journal of Engineering and Technological Sciences 2: 21-40.

[16] Donoghue, A. M. (2004): Occupational health hazards in mining: an overview. Occupational Medicine 54: 283-289.

[17] Göksu, G., Karabulut, M. (2014): Kahramanmaraş şehir merkezinde gürültü kirliliğinin değerlendirilmesi (in Turkish). - Coğrafyacılar Derneği Uluslararası Kongresi, Muğla, 859-866.

[18] Ilgar, R. (2012): A preliminary study noise pollution source for urban vehicle traffic in Canakkale. - Zeitschrift für die Welt der Türken 4(1): 253-267.

[19] Kablan, A. (2012): Noise pollution at railways and disposal methods, evaluation of the related legislation (Demiryollarında gürültü kirliliği ve bertaraf yöntemleri, ilgili mevzuatın değerlendirilmesi). - MSc. Thesis, Graduate School of Natural and Applied Sciences, Bahçeşehir University, İstanbul.

[20] Kalıpçı, E. (2017): Spatial analysis of traffic related noise pollution in the center of Avanos District (Avanos ilçe merkezinde trafik kaynaklı gürültü kirliliğinin mekansal analizi). - Nevşehir Journal of Science and Technology 6(1): 20-29.

[21] Karaday1, S. (2001): Preparation of Bursa's noise map resulted by traffic (Bursa İli'nin trafik kaynaklı gürültü haritasının hazırlanması). - MSc. Thesis, Graduate School of Natural and Applied Sciences, Sakarya University, Sakarya.

[22] Kurra, S. (2009): Çevre Gürültüsü ve Yönetimi I-II-III (in Turkish). - İstanbul Bahçeşehir Üniversitesi Yayınları, İstanbul.

[23] Morgül, Ö. K., Dal, H. (2012): A preliminary study on noise pollution of sakarya province city centre (Sakarya ili şehir merkezinin gürültü kirliliği üzerine bir ön çalışma). - Sakarya University Journal of Science 16(2): 83-91.

[24] Neitzel, R., Gershon, R. M., Zeltser, M., Canton, A., Akram, M. (2009): Noise levels associated with New York City's mass transit systems. - American Journal of Public Health 99(8): 1393-1399.

[25] Oruç, K. Ş. (2017): Environmental Noise Pollution Caused by Speed Train (Hızlı trenin neden olduğu çevresel gürültü kirliliği). - MSc. Thesis, Gazi University, Graduate School of Natural and Applied Sciences, Ankara.

[26] Özbıçakçı, Ş., Çapık, C., Aydoğdu Gördes, N., Ersin, F., Kıssal, A. (2012): Assesment of noise level and hearing conservation in a school community (Bir Okul Toplumunda Gürültü Düzeyi Tanılaması ve Duyarlılık Eğitimi). - Education and Science 37(165): 238-245.

[27] Özer, S. (2014): Determination of noise pollution in urban parks of Erzurum: in the case of Aziziye Park (Erzurum kent parklarındaki gürültü kirliğinin belirlenmesi: aziziye parkı örneğinde). - Journal of Adnan Menderes University Agricultural Faculty 11(2): 7-11.

[28] Özer, S. (2015): Noise level in the parks in the city centres; the sample of Yakutiye Park (Kent Merkezlerindeki Parklarda Gürültü Düzeyi: Yakutiye Parkı Örneğinde). - Journal of the Institute Science and Technology 5(3): 43-48.

[29] Özer, S. (2017): Present situation analysis of noise pollution in city parks of Erzurum in the sample of Yüzüncüyıl Park (Erzurum Kenti Yüzüncüyıl Parkı Örneğinde Kent Parklarındaki Gürültü Kirliğinin Mevcut Durum Analizi). - Alınteri Journal of Agricultural Sciences 32(1): 39-44.

[30] Rosenberg, J. (1991): Jets over Labrador and Quebec: noise effects on human health. Canadian Medical Association Journal 144(7): 869-875. 
[31] Sakarya, E. (2016): Effects of noise on working life and noise analysis in a construction site (Gürültünün çalışma hayatına etkileri ve bir inşaat şantiyesinde gürültü analiz çalışması). - MSc. Thesis, Health Sciences Institute, Üsküdar University, İstanbul.

[32] Sharma, A., Bodhe, G. L., Schimak, G. (2014): Development of a traffic noise prediction model for an urban environment. - Noise and Health 16(68): 63-67.

[33] Singh, N., Davar, S. C. (2004): Noise Pollution-Sources, Effects and Control. - Journal of Human Ecology 16(3): 181-187.

[34] Szeremeta, B., Zannin, P. H. T. (2009): Analysis and evaluation of soundscapes in public parks through interviews and measurement of noise. - Science of the Total Environment 407: 6143-6149.

[35] Şahin, E. (2003): Noise control techniques-a case study (Gürültü kontrol yöntemleri-bir uygulama). - Journal of the Faculty of Engineering and Architecture of Gazi University 18(4): 67-80.

[36] Şerefhanoğlu, M. (1991): Gürültü ile Savaşımda Temel İlkeler ve İnsan Etkeni (in Turkish). - Noise Symposium, Konya, 1-6.

[37] Tür, M. B. (2016): The effect of noise on blood pressure and sleep in health workers (Sağlık çalışanlarında gürültünün kan basıncı ve uyku üzerine etkisi). - MSc. Thesis, Health Sciences Institute, Dokuz Eylül University, İzmir.

[38] Ünver, E. (2008): Determination of noise pollution due to traffic and recreation: a case study of Çorlu (Trafik ve rekreasyonel kullanım kaynaklı gürültü kirliliğinin belirlenmesi: çorlu örneği). - MSc. Thesis, Graduate School of Natural and Applied Sciences, Namık Kemal University, Tekirdağ.

[39] Yerli, Ö., Demir, Z. (2015): An investigation of the noise differences in the settlement areas of Düzce (Düzce kenti yerleşim bölgelerindeki gürültü farklarının incelenmesi). Erciyes University Journal of the Institute of Science and Technology 31(1): 32-42.

[40] Zannin, P. H. T., Ferreira, A. M. C., Szeremetta, B. (2006): Evaluation of Noise Pollution in Urban Parks. - Environmental Monitoring and Assessment 118: 423-433. 